\title{
PENGARUH DUKUNGAN KELOMPOK KLUB STROKE BAGI ANGGOTANYA DALAM PERAWATAN KLIEN PASCA STROKE TERHADAP KEJADIAN STROKE BERULANG
}

\author{
Suhadi*, Waluyanti Purboningsih \\ Sekolah Tinggi lmu Kesehatan St. Elisabeth Jl. Kawi No. 11 Semarang, Jawa Tengah, Indonesia 50232 \\ *stsuhadi9264@gmail.com (+628122849439)
}

\begin{abstract}
ABSTRAK
Penyakit Stroke menimbulkan gangguan dan gejala sisa bagi klien dan keluarganya, baik secara fisik, psikologis, sosial dan ekonomi. Dalam waktu 10 tahun, kejadian stroke akan berulang sebesar $40 \%$. Kejadian stroke berisiko ulang ini disebabkan ketidakmampuan keluarga dalam merawat klien paska stroke. Dukungan kelompok sangat diperlukan bagi keluarga yang merawat anggota keluarga paksa mengalami stroke. Klub stroke RS St Elisabeth Semarang merupakan salah satu bentuk kelompok yang memberikan dukungan bagi keluarga yang merawat anggota keluarga paska stroke dengan memberikan dukungan informasi, emosional, penghargaan dan instrumental. Penelitian ini bertujuan untuk mengetahui apakah ada kejadian stroke brulang bagi anggota klub srtoke. Penelitian ini merupakan penelitian kuantitatif dengan metode penelitian cross sectional, desain studi kasus. Sampel penelitian sebanyak 32 responden, diambil menggunakan metode purpossive sampling. Data dikumpulkan melalui kuesioner. Berdasarkan analisis univariat diperoleh data anggota klub yang mendapatkan dukungan kelompok baik 90,6\% dan yang memperoleh dukungan kelompok kurang baik 9,4\%; anggota yang mengalami kejadian stroke berulang sebanyak $25 \%$ dan yang tidak mengalami stroke berulang sebanyak 75\%. Berdasarkan analisis bivariat menggunakan uji Fisher diperoleh $p$ value 0,408 ( $p$ value $>0,05$ ). Tidak ada pengaruh dukungan kelompok Klub Stroke bagi anggotanya dalam perawatan klien paska stroke terhadap kejadian stroke berulang di Kota Semarang dengan $p$ value $>0,05$.
\end{abstract}

Kata kunci: dukungan klub stroke; perawatan; kejadian stroke berulang

\section{EFFECT OF STROKE CLUB GROUP SUPPORT FOR THE MEMBERS OF THE POST STROKE CLIENT TREATMENT TOWARD REPEAT STROKE EVENT}

\begin{abstract}
Stroke causes disturbances and sequelae for the client and his family, both physically, psychologically, socially and economically. Within 10 years, the incidence of stroke will recur by $40 \%$. The risk of re-stroke is caused by the inability of the family to care for clients after a stroke. Group support is very much needed for families caring for family members who have had a stroke. St Elisabeth Hospital Semarang stroke club is one form of a group that provides support for families caring for family members after a stroke by providing information, emotional, appreciation and instrumental support. This study aims to determine whether there are recurrent stroke events for members of the stroke club.This research is a quantitative research with cross sectional research method, case study design. The research sample of 32 respondents, taken using purposive sampling method. Data collected through a questionnaire. Based on univariate analysis, it was obtained the data of club members who received good group support $90.6 \%$ and those who received poor group support 9.4\%; members who
\end{abstract}


experienced recurrent stroke events as much as $25 \%$ and who did not experience recurrent strokes as much as 75\%. Based on bivariate analysis using Fisher's test, $p$ value was 0.408 ( $p$ value> 0.05). There is no influence of the Stroke Club group support for its members in the care of post stroke clients on the incidence of recurrent strokes in the city of Semarang with $p$ value $>0.05$.

Keywords: recurrent stroke events; stroke club support; treatment

\section{PENDAHULUAN}

Stroke merupakan kehilangan fungsi otak sebagai akibat dari berhentinya suplai darah ke bagian otak, yang umumnya merupakan akumulasi dari penyakit serebrovaskuler selama beberapa tahun (Ariani, 2012). Stroke merupakan salah satu penyakit degeneratif yang dialami lansia, namun juga dapat dialami oleh semua golongan umur.

Klien paska stroke pada umumnya mengalami gejala sisa atau kecacatan secara fisik dan psikologis, yang berupa gangguan fungsi motorik, sensorik dan kognitif. Kecacatan ini menimbulkan hambatan kemampuan fungsional mulai dari kemampuan bergerak sampai kemampuan bersosialisasi dengan lingkungan sekitar (Pinzon \& Asanti, 2010). Dampak lain bagi klien paska stroke juga menyebabkan beban sosial, ekonomi dan psikologis bagi keluarga yang merawat. Semakin tinggi derajat kecacatan penderita semakin tinggi pula beban bagi keluarga. World Health Organization (WHO) menyebutkan bahwa stroke adalah penyebab utama kecacatan yang menurunkan mobilitas pada lebih dari $65 \%$ klien paska stroke.

Stroke dapat berulang selama periode dan setelah pemulihan fungsi neurologis. Pemulihan fungsi neurologis klien paska stroke membutuhkan waktu 3 sampai 18 bulan (Association, 2009). Rendahnya kesadaran akan faktor risiko stroke, kurang dikenalinya gejala stroke, belum optimalnya pelayanan paska stroke serta rendahnya ketaatan terhadap program terapi berperan penting dalam peningkatan kejadian stroke berulang. Data statistik dari Stroke Association di Eropa menunjukkan bahwa kemungkinan terjadinya stroke berulang adalah $3,1 \%$ dalam 30 hari; $11,1 \%$ dalam 1 tahun; 2,4\% dalam 5 tahun; dan 39,2\% dalam waktu 10 tahun. Dalam penelitian lain juga disebutkan bahwa sekitar $40 \%$ kejadian stroke akan berulang dalam kurun waktu 10 tahun (Hardie, Hankey, Jamrozik, Broadhurst, A, 2008). Pada penelitian epidemiologi yang dilakukan oleh Universitas Indonesia didapatkan bahwa 19,9\% kejadian stroke merupakan kejadian stroke berulang (Rasyid \& Soertidewi, 2007).

Peran keluarga sangat penting karena keluarga yang terlibat langsung selama perawatan paska stroke di rumah. Pemulihan pasien stroke akan sangat terbantu jika keluarga memberikan dorongan, memperlihatkan kepercayaan pada perbaikan pasien dan memungkinkan pasien melakukan banyak hal dan hidup semandiri mungkin. Keluarga berperan memberikan dukungan kepada anggota keluarga yang sakit. Dukungan tersebut berupa dukungan emosional, dukungan informasional, dukungan penghargaan dan dukungan instrumental (Wurtiningsih, 2012). Keluarga dapat mengalami perubahan dalam kehidupannya karena mereka harus belajar bagaimana merawat klien paska stroke di rumah (Pierce, 2010). 
Hasil studi pendahuluan melalui observasi terhadap keluarga dengan klien paska stroke menunjukkan bahwa dukungan keluarga mempengaruhi perawatan klien paska stroke. Klien paska stroke yang tinggal dalam keluarga dan tidak memperoleh dukungan mengalami stroke berulang bahkan lebih dari satu kali. Sebaliknya, klien paska stroke yang tinggal dalam keluarga dan memperoleh dukungan dapat bertahan hidup meskipun dalam keterbatasan fisik. Dukungan keluarga dapat meningkatkan kualitas hidup bagi klien paska stroke.

Klub stroke sebagai wadah kegiatan penderita paska stroke menjadi kelompok pendukung bagi klien paska stroke dan keluarga mereka. Di dalam kegiatannya klub stroke mempunyai misi antara lain memfasilitasi para klien paska stroke agar kepercayaan dirinya pulih, menyebarluaskan pengetahuan tentang stroke dan melaksanakan kampanye hidup sehat untuk mencegah stroke dan stroke ulang, serta meningkatkan kualitas hidup klien paska stroke (Pandji, 2011).

Hasil studi pendahuluan yang dilakukan oleh peneliti melalui wawancara kepada beberapa anggota klub stroke RS St. Elisabeth Semarang, menyatakan bahwa anggota klub tersebut merasa senang mengikuti kegiatan klub. Mereka mengatakan dengan mengikuti kegiatan klub stroke dapat berbagi cerita dengan anggota lain dan menambah pengetahuan. Meskipun mereka tidak bisa datang dalam kegiatan, para anggota tetap bisa berkomunikasi melalui media sosial grup whatsapp sehingga keluarga mendapatkan informasi tentang kesehatan pasien paska stroke.
Klub stroke merupakan salah satu bentuk kelompok pendukung yang berfungsi memberikan dukungan baik itu bagi pasien dan keluarganya. Dukungan yang diberikan berupa dukungan informasi, dukungan emosional dan dukungan penghargaan. Dukungan kelompok dapat menambah pengetahuan dan kualitas hidupnya. Hal ini dapat mengurangi stres sehingga kualitas hidup meningkat. Dukungan dapat menambah pengetahuan dan informasi sehingga keluarga mampu merawat anggota keluarganya yang sakit. Peneliti memandang bahwa kelompok pendukung sangat bermanfaat bagi klien paska stroke dan keluarganya.

Tujuan Penalitian ini adalah untuk mengetahui pengaruh dukungan kelompok Klub Stroke bagi anggotanya dalam perawatan klien paska stroke terhadap kejadian stroke berulang di RS St. Elisabeth Semarang. Penelitian ini penting untuk dilakukan supaya dapat mengetahui apakah angota klub stroke mengalami stroke berulang setelah menjadi anggota klub stroke melalui penelitian kuantitatif.

\section{METODE}

Penelitian ini merupakan penelitian kuantitatif menggunakan desain deskriptif analitik dengan pendekatan cross sectional yaitu desain penelitian analitik. Populasi dalam penelitian ini adalah keluarga anggota Klub Stroke Rumah Sakit St. Elisabeth Semarang. Berdasarkan data dari pengurus Klub Stroke, jumlah anggota klub Stroke RS St. Elisabeth Semarang sebanyak 52 orang. Peneliti meneliti keseluruhan populasi sebagai sampel (total sample). Peneliti menetapkan sampel berdasarkan kriteria inklusi dan eksklusi. Kriteria inklusi yaitu keluarga dari anggota Klub Stroke RS St. 
Elisabeth Semarang yang pernah mengikuti kegiatan klub minimal 2 kali pertemuan. Untuk kriteria eksklusi yaitu keluarga yang tidak bersedia menjadi responden penelitian. Sampel yang telah memenuhi kriteria inklusi dan eksklusi dalam penelitian ini adalah sebanyak 32 orang. Uji statistik dalam penelitian ini memakai uji alternatif yaitu uji Fisher, karena menggunakan uji Chi Square.

\section{HASIL}

\section{Karakteristik Responden}

Tabel 1 menggambarkan distribusi frekuensi jenis kelamin anggota Klub
Stroke RS St. Elisabeth Semarang. Anggota Klub Stroke mayoritas berjenis kelamin laki-laki dan berusia middle age. Lama keikutsertaan dalam Klub Stroke RS St. Elsabeth Semarang, mayoritas anggota yang mengikuti klub stroke selama 0 - 5 tahun. Mayoritas dukungan klub stroke yang diterima keluarga klien paska stroke adalah baik. Sedangkan untuk distribusi frekuensi kejadian stroke berulang yang dialami klien paska stroke setelah menjadi anggota klub stroke RS St. Elisabeth Semarang, mayoritas anggota tidak mengalami stroke ulang.

Tabel 1.

KarakteristikResponden $(n=32)$

\begin{tabular}{lcc}
\hline \multicolumn{1}{c}{ Karakteristik } & f & $\%$ \\
\hline Jenis kelamin & 23 & 71,9 \\
\hline Laki-laki & 9 & 28,1 \\
\hline Perempuan & & \\
\hline Kelompok lansia & 24 & 75 \\
Middle age & 7 & 21,9 \\
Elderly & 1 & 3,1 \\
Old & & \\
\hline Lama keikutsertaan (th) & 20 & 62,5 \\
$0-5$ & 12 & 37,5 \\
6-10 & 3 & 9,4 \\
Dukungan klub & 29 & 90,6 \\
Kurang baik & & \\
Baik & 8 & 25 \\
\hline Kejadian stroke ulang & 24 & 75 \\
Ya & & \\
Tidak & & \\
\hline
\end{tabular}

Tabel 2.

Pengaruh dukungan kelompok Klub Stroke bagi anggotanya dalam perawatan klien paska stroke terhadap kejadian stroke berulang $(n=32)$.

\begin{tabular}{|c|c|c|c|c|c|c|}
\hline \multirow{3}{*}{$\begin{array}{l}\text { Dukungan } \\
\text { kelompok }\end{array}$} & \multicolumn{4}{|c|}{ Kejadian stroke ulang } & \multirow{3}{*}{ Total } & \multirow{3}{*}{$p$ value } \\
\hline & \multicolumn{2}{|c|}{ Ada } & \multicolumn{2}{|c|}{ Tidak ada } & & \\
\hline & $\mathrm{f}$ & $\%$ & $\mathrm{f}$ & $\%$ & & \\
\hline Kurang baik & 0 & 0 & 3 & 9,4 & 3 & 0408 \\
\hline Baik & 8 & 25 & 21 & 65,6 & 29 & 0,408 \\
\hline
\end{tabular}


Peneliti menggunakan uji stastistik alternatif yaitu uji Fisher karena pada uji Chi Square tabel $2 \times 2$, terdapat lebih dari $20 \%$ sel yang mempunyai expected count kurang dari 5 dan terdapat 1 sel yang memiliki observed count 0 maka tidak memenuhi kriteria uji Chi Square. Pada uji Fisher tersebut didapatkan $p$ value 0,408 ( $\mathrm{p}$ value $>$ 0,05) maka $\mathrm{H} 0$ diterima dan $\mathrm{H} 1$ ditolak yang artinya tidak ada pengaruh antara dukungan kelompok Klub Stroke bagi anggotanya dalam perawatan klien paska stroke terhadap kejadian stroke berulang di RS St. Elisabeth Semarang.

\section{PEMBAHASAN}

\section{Jenis Kelamin Responden}

Jenis kelamin laki-laki merupakan salah satu faktor risiko stroke yang tidak dapat diubah. Laki-laki lebih berisiko terserang stroke daripada wanita (Pinzon \& Asanti, 2010). Hal ini terkait dengan hormonal yang mempengaruhi pembuluh darah yaitu hormon esterogen. Kadar hormon esterogen pada laki-laki lebih sedikit daripada perempuan. Hormon esterogen berperan dalam menekan kadar Lipoprotein (a) atau Lp (a). Kadar Lp (a) rata-rata adalah $2 \mathrm{mg} / \mathrm{dl}$, apabila meningkat sampai 20-30 mg/dl maka akan muncul risiko penyakit jantung koroner dan stroke. Lp(a) berperan sebagai penggumpal yang kemudian bersamasama plak yang ada dalam pembuluh darah arteri akan menyumbat aliran darah (Farida,2009). Apabila aliran darah ke otak berkurang maka suplai oksigen juga berkurang. Hal inilah yang dapat memicu terjadinya stroke (Nugroho, 2009).

Penelitian yang dilakukan oleh Siti tentang faktor risiko stroke usia muda juga menyajikan data responden lakilaki lebih banyak daripada perempuan (55\%) (Endang.,2012). Penelitian ini sejalan dengan penelitian-penelitian sebelumnya bahwa responden laki-laki lebih banyak dibandingkan perempuan.

\section{Usia Anggota Klub Stroke}

Usia merupakan salah satu faktor risiko stroke yang tidak dapat diubah. Semakin tua usia seseorang akan semakin mudah terserang stroke. Stroke dapat terjadi pada semua usia namun $70 \%$ kasus stroke terjadi pada usia di atas 65 tahun (Pinzon \& Asanti, 2010). Semakin tua usia strktur pembuluh darah menjadi berubah, hal ini dikaitkan dengan proses degeneratif yang terjadi secara alamiah. Pembuluh darah menjadi lebih kaku dan kurang elastis sehingga mudah terbentuk plak. Plak yang terbentuk menyebabkan aliran darah menjadi tidak lancar sehingga suplai oksigen ke jaringan otak berkurang. Hal inilah yang memicu terjadinya stroke (Farida, 2009). Klasifikasi lansia menurut WHO yaitu usia pertengahan/middle age (45-59 tahun), lansia/elderly (60-74 tahun), lansia tua/old (75-90 tahun) dan lansia sangat tua/very old (di atas 90 tahun) (Taylor, 2009). Hasil penelitian pada penelitian ini sejalan dengan penelitianpenelitian sebelumnya yang menyebutkan bahwa seluruh responden adalah kelompok lansia.

\section{Dukungan Kelompok Klub Stroke}

Hasil penelitian menunjukkan bahwa anggota klub yang aktif mengikuti kegiatan klub stroke mempunyai dukungan kelompok baik sebesar 90,6\%. Dukungan kelompok dapat diperoleh melalui keterlibatan aktif dalam kegiatan kelompok dukungan kelompok yang baik dapat meningkatkan kualitas hidup. Kualitas hidup yang baik akan membantu pemulihan klien paska stroke. Hasil penelitian ini sejalan dengan penelitian Endang yang menyebutkan bahwa 
dukungan kelompok Persadia yang besar dapat meningkatkan upaya penyembuhan (Endang, 2012). Revi dalam penelitiannya mengungkapkan bahwa ada hubungan kelompok sebaya dengan kualitas hidup ODHA ( $p$ value 0,000) (Mansjoer, 2000).

Gangguan yang dialami klien paska stroke mengakibatkan stres bagi keluarga dan klien paska stroke sendiri karena ketidakmampuan dalam merawat di rumah, oleh karena itu klien dan keluarga membutuhkan dukungan. Klub stroke merupakan salah satu bentuk kelompok pendukung bagi klien paska stroke dan keluarganya. Klub stroke menjadi wadah bagi klien paska stroke untuk melakukan kegiatan bersama dengan klien paska stroke yang lain. Klub stroke juga menjadi tempat keluarga dan pasien mendapatkan berbagai informasi tentang stroke (Dharma, 2011). Dukungan kelompok terdiri dari dukungan informasi, dukungan emosional, dukungan penghargaan dan dukungan instrumental.

Keikutsertaan klien paska stroke dalam klub stroke juga membuat koping pasien meningkat. Agustina dalam penelitiannya tentang koping stres klien paska stroke yang mengikuti klub stroke mengatakan klien paska stroke yang mengikuti klub stroke mempunyai strategi koping yang baik dalam menghadapi stres. Klien paska stroke yang memakai strategi problem focused sebanyak $57,6 \%$ dan emotional focused sebanyak 42,4\% (Dharma, 2011).

Stroke yang dialami oleh seseorang akan membuat perubahan bagi klien dan keluarganya. Hal ini dapat terjadi karena klien stroke mengalami gangguan baik itu fisik, sosial, ekonomi dan psikologis. Gangguan yang dialami dapat menyebabkan stres karena ketidakmampuan dalam perawatan di rumah, oleh karena itu dukungan sangat diperlukan. Taylor menyatakan bahwa dukungan bisa efektif dalam mengatasi tekanan psikologis pada masa-masa sulit dan menekan kemudian dukungan sosial juga dapat menurunkan sakitnya (Taylor, 2009).

\section{Kejadian Stroke Berulang pada Anggota Klub Stroke}

Stroke dapat berulang jika klien dan keluarga sebagai pendukung tidak melakukan upaya pencegahan stroke ulang. Pencegahan stroke berulang dilakukan dengan cara mengenal faktor risiko dan mengendalikannya, mengkonsusi makanan sesuai diit, rutin minum obat serta kontrol ke dokter secara rutin. Klub stroke menjadi salah satu kelompok pendukung bagi klien paska stroke dan keluarganya untuk mendapatkan dukungan informasi, emosional, instrumen dan penghargaan. Dukungan dalam klub membantu meningkatkan kualitas hidup klien paska stroke dan pengetahuan terkait stroke dan penatalaksanaannya. Peningkatan kualitas hidup dan pengetahuan tentang perawatan paska stroke akan membantu klien paska stroke dalam mempertahankan kesehatannya.

\section{Pengaruh Dukungan Kelompok Klub Stroke bagi Anggotanya dalam Perawatan Klien Paska Stroke terhadap Kejadian Stroke Berulang}

Faktor risiko stroke yang dapat diubah antara lain hipertensi, diabetes mellitus, dislipdemia, obesitas, stres dan merokok (Friedman, 2010). Stroke berisiko untuk kambuh apabila faktor risiko tersebut tidak dikendalikan. Data statistik dari Stroke Assiciation di Eropa, menunjukkan bahwa kemungkinan terjadinya stroke berulang adalah $3,1 \%$ 
dalam waktu 30 hari, $11,1 \%$ dalam waktu 1 tahun dan 39,2\% dalam waktu 10 tahun (Stroke Association,2013). Hal ini menunjukkan semakin lama klien paska stroke bertahan setelah serangan stroke, semakin besar pula risiko terjadinya stroke ulang. Oleh karena itu perlu dilakukan upaya untuk mencegah stroke ulang paska stroke. Wardhana mengatakan upaya yang dapat dilakukan untuk menanggulangi terjadinya serangan stroke berulang adalah dengan menjalankan perilaku hidup sehat, mengendalikan faktor risiko, melakukan kontrol rutin, mengkonsumsi makanan yang sehat, tidak merokok dan harus mengenali tanda-tanda stroke. Jika salah satu upaya pencegahan tidak dijalankan maka risiko terjadinya stroke berulang semakin besar.

Pendidikan kesehatan yang agresif dan persisten untuk pasien paska stroke dan manajemen faktor risiko stroke sangat penting untuk mengurangi kekambuhan stroke. Pendidikan kesehatan bisa didapatkan melalui tenaga kesehatan, media sosial dan kelompok pendukung seperti klub stroke. Peneliti belum menemukan jurnal penelitian tentang pengaruh dukungan kelompok klub stroke terhadap kualitas hidup paska stroke. Penelitian yang serupa tentang dukungan kelompok dilakukan oleh Muhamad, yang mengatakan terdapat hubungan positif antara dukungan kelompok dengan kualitas hidup pada penderita DM yang aktif di Persadia Cabang Surakarta dengan nilai $p$ value 0,017, semakin baik dukungan kelompok maka kualitas hidup penderita DM semakin meningkat .

Tabel 2 tentang analisis uji statistik pengaruh dukungan kelompok klub stroke dalam perawatan klien paska stroke terhadap kejadian stroke di RS
St. Elisabeth Semarang didapatkan bahwa dukungan klub stroke tidak berpengaruh terhadap kejadian stroke berulang. Penelitian ini tidak sejalan dengan penelitian sebelumnya tentang dukungan kelompok. Peneliti menemukan bahwa 8 orang dari anggota klub mengatakan bahwa kelompok klub stroke memberikan dukungan yang baik tetapi mereka mengalami stroke ulang. Mereka telah menjadi anggota klub stroke selama lebih dari 5 tahun. Tiga orang mengalami stroke ulang karena tidak rutin minum obat. Seorang mengatakan selalu rutin minum obat dan kontrol dokter tetapi pada stroke terakhir, klien mengatakan karena gula darah tinggi sedangkan selama ini tidak pernah kontrol gula darah. Dua orang mengatakan jarang kontrol ke dokter karena merasa badannya sudah enak. Seorang mengatakan orang tuanya mengalami stroke setelah ada masalah dengan adiknya. Seorang lagi mengatakan mengalami stroke ulang karena tidak menjaga pola makan.

Peneliti menemukan bahwa 3 orang dari anggota klub mengatakan bahwa kelompok klub stroke memberikan dukungan yang kurang baik tetapi mereka tidak mengalami stroke ulang. Dua orang menjadi anggota klub selama 2 tahun dan seorang lagi menjadi anggota selama 3 tahun. Mereka mengatakan mendapatkan informasi tentang perawatan paska stroke dari dokter. Mereka selalu kontrol dokter dan rutin minum obat.

Menurut analisis peneliti dari hasil kuesioner tentang pengaruh dukungan kelompok Klub Stroke bagi anggotanya dalam perawatan klien paska stroke terhadap kejadian stroke berulang di RS St. Elisabeth Semarang, menunjukkan bahwa kejadian stroke ulang tidak 
dipengaruhi oleh baik tidaknya dukungan kelompok dan lama tidaknya keikutsertaan dalam klub stroke. Stroke berulang ditentukan oleh kepatuhan keluarga dalam merawat dan klien paska stroke sendiri dalam menjaga pola hidup sehat. Penelitian ini tidak menunjukkan ada pengaruh dukungan kelompok terhadap kejadian sroke berulang, namun keberadaan klub stroke sendiri bermanfaat baik bagi anggotanya. Pada tabel 4.7 tentang distribusi frekuensi kejadian stroke berulang di Klub Stroke terlihat bahwa $25 \%$ saja responden yang mengalami stroke ulang. Pada hitungan kasar, angka ini lebih kecil daripada prevalensi stroke berulang dalam penelitian sebelumnya yaitu sekitar $40 \%$. Hal ini merupakan salah satu bentuk dukungan klub stroke bagi anggota sehingga kualitas hidup semakin meningkat.

\section{SIMPULAN}

Pada uji Fisher tersebut didapatkan $p$ value 0,408 ( $\mathrm{p}$ value > 0,05) maka $\mathrm{H} 0$ diterima dan $\mathrm{H} 1$ ditolak yang artinya tidak ada pengaruh antara dukungan kelompok Klub Stroke bagi anggotanya dalam perawatan klien paska stroke terhadap kejadian stroke berulang di RS St. Elisabeth Semarang.

\section{DAFTAR PUSTAKA}

Ariani, T. (2012). Sistem Neurobehaviour. Jakarta : Salemba Medika.

Pinzon, R. \& Asanti, L. (2010). Awas Stroke! Pengertian, Gejala, Tindakan, Perawatan \& Pencegahan. Jakarta : ANDI, 2010.

Association, A. H. (2009). Strength Training Improves Upper-Limb Function in Individuals With Stroke.
Stroke Association. (2013). Stroke Statistics.

Hardie K, Hankey GJ, Jamrozik K, Broadhurst RJ, A. C. (2008). Ten Years Risk of First Recurrent Stroke and Disability After First Ever Stroke in the Perth Community Stroke Study. AHA J.35, 731-735.

Wurtiningsih, B. (2012). Dukungan Keluarga Pada Pasien Stroke Di Ruang Saraf RSUP Dr. Kariadi Semarang. med hosp1, 57-59.

Pierce, E. Al. (2010). Questions Caregivers Asked in Caring for Persons with Stroke. Available at: http//:ojni-orj/Pierce/PDF.2010

Pandji, D. (2011). Stroke Bukan Akhir Segalanya. Jakarta : PT Elex Media Kompitudo.

Mansjoer, A. (2000). Kapita Selekta Kedokteran Jilid 1. Jakarta : Media Aesculapius.

Deriega, V. J. (1996). Friendship and Social Interactions. Jakarta : Springer-Verlag.

Friedman, M. (2010). Buku Ajar Keperawatan Keluarga: Riset, Teori dan Praktek. Jakarta : EGC.

Dharma, K. K. (2011). Metodologi Penelitian Keperawatan. Jakarta : CV. Trans Info Media.

Swarjana, I. K. (2012). Metodologi Penelitian Kesehatan. Jakarta : CV Andi Offset.

Rahardjo, S. (2011). Hubungan Tingkat Pendidikan dan Pengetahuan dengan Perilaku Keluarga Sadar Gizi pada Masyarakat Perkotaan dan Perdesaan di Kabupaten 
Banyumas. 150-158.

Suyono, J. (2000). Biokimia Kedokteran

Dasar: Sebuah Pendekatan

Klinis. Jakarta : EGC.

Farida. (2009). Mengantisipasi Stroke. Jakarta : Bukubiru.

Nugroho, W. (2009). Komunikasi dalam keperawatan gerontik. Jakarta :EGC.

Endang. (2012). Pengaruh Keterlibatan Aktf dalam Kelompok Dukungan (Persadia) erhadap Tingkat Kepatuhan Pengobatan Penderita Diabetes Mellitus di Puskesmas Pakis Surabaya Kartasura. J. Psikol. Klin. dan Kedokt.01, 02.

Taylor. (2009). Psikologi Sosial. Jakarta : Kencana Prenada Group.

Rasyid A, Soertidewi L. (2007). Unit stroke: Manajemen Stroke Secara Komprehensif. Jakarta: Balai Penerbit. 
Jurnal Penelitian Perawat Profesional, Volume 2 No 2 Hal 217 -226, Mei 2020 Global Health Science Group 